\title{
Lecturers' Participation in Applying Blended Learning in Islamic Higher Education in Indonesia
}

\author{
Asfiati Shamad ${ }^{1, *}$, Ismail Suardi Wekke ${ }^{2}$ \\ ${ }^{1}$ Institut Agama Islam Negeri (IAIN) Padangsidimpuan, Indonesia \\ ${ }^{2}$ Sekolah Tinggi Agama Islam Negeri (STAIN) Sorong, Indonesia
}

Received August 30, 2019; Revised November 11, 2019; Accepted November 18, 2019

Copyright@2019 by authors, all rights reserved. Authors agree that this article remains permanently open access under the terms of the Creative Commons Attribution License 4.0 International License

\begin{abstract}
Digital-based technology has penetrated all aspects of people's lives, including in the world of education, where a learning method called blended learning emerged. This method allows learning to be done anywhere and anytime using the internet. This study aimed to determine the weaknesses and strengths of blended learning in completing curriculum curriculums and lecture programs, as well as to know whether or not the lecturers have participated in implementing it. The method used was qualitative, with a case-study approach, using instruments in the form of observations, interviews, and notes from individual experiences or behavior. The data sources were the researchers themselves, supported by outside observers. This study found that the lecturers had participated in implementing blended learning based on models.
\end{abstract}

Keywords Participation, Blended Learning, Industrial Revolution 4.0

\section{Intoduction}

Every aspect of human life continues to experience changes and developments, including in the education, technology, information, and even social fields. All of these developments and changes aim to achieve progress, especially in this era of digital-based technology that is marked by artificial intelligence and supercomputers with significant changes in business patterns and people's lives.

In the education world, developments occur in terms of learning systems, strategies, professionalism, as well as everything that discusses its ups and downs. Each type and level of education, including tertiary institutions, seeks to achieve success, by producing quality cadres of the nation. In this effort, lectures are the most responsible ones for advancing and educating students.

According to Yulianto (2018), lecturers are professionals that require sufficient technical expertise and knowledge to support their professionalism. Lecturers who have expertise can transform knowledge using various methods and strategies. All the knowledge transferred should be going hand in hand with all developments, especially at this time, where all things become completely digital and online (Kurniasih, 2019). Technology is functioning everywhere as easy as tapping a screen by a single finger, and infrastructure is growing rapidly. The development of unicorns in Indonesia is increasing rapidly. Lecturers should be involved to participate in changing the learning paradigm in the direction of being able to follow and respond to every change.

The change in the learning paradigm from teacher-centered to learner-centered learning is an effort to increase motivation, learning quality, and teaching material, as well as independence. The learner-centered one is expected to overcome the problem of limited classrooms and other infrastructure, as well as time constraints. The most appropriate method is e-learning, which is one of the products of the industrial revolution 4.0, characterized by an increase in digitalization of manufacturing which is driven by four factors: 1) an increase in data volume, computational power, and connectivity; 2) the emergence of analysis, capabilities, and business intelligence; 3) the occurrence of new forms of interaction between humans and machines; and 4) improvement of digital transfer instructions to the physical world (Martikasari \& Dharma, 2018).

To implement e-learning, an institution may choose two electronic-based learning models, namely synchronous and asynchronous learning models (Suprapto, 2019). Synchronous learning is a way to deliver material or a delivery system between two main actors, namely lecturers and students. In this model, lecturers and students are interacting with each other directly in one time online. Thus, the institutions should provide all supporting facilities and infrastructure, including well-organized 
Wi-Fi, bandwidth, and application networks.

The second model is asynchronous learning, which does not need facilities and infrastructure as complete as of the other one. It focuses more on improving the quality and substance of teaching materials. Therefore, there is no significant obstacle in its application in lectures. This model is also known as the blended learning method, which has four levels, namely activity, course, program, and institution levels (Graham, 2006).

To facilitate implementing blended learning, lecturers should first make adjustments to the courses taught. In this study, lecturers that guided micro-teaching courses at the Faculty of Tarbiyah and Teacher Training (FTIK) of Padangsidimpuan apply blended learning in semester VI.

According to Christensen, Horn, \& Staker (2013), there are seven ways in implementing blended learning, two of which are the stati- and lab-rotations, which are applied in early learning. The third model is the individual rotation, which is implemented by rotating the entire station that has been arranged by the lecturer. Rotation scheduling is first done for students.

The fourth model, namely flipped classroom, combines class time with homework. Students do homework using online coursework, while lecturers use their teaching time by making assignments and learning projects.

The fifth is flex, which is tailored to the needs of students where the lecturer provides learning and teaching support based on flexibility following student needs through curriculum and content. This model offers supervision.

The sixth model is La Carte, which makes it possible to take online courses with lecturers with previously recorded materials, in addition to classroom learning materials. This model is the right choice for campuses that do not yet provide elective courses.

The last one is enriched virtual, which is an alternative to the e-learning model. This model allows students to complete all materials online and still requires them to attend face-to-face learning activities in class as needed.

\section{Methods}

This study, using the case study method, aimed to know deeply how the lecturers implement blended learning, to help them to achieve better adjustments (Muh Fitrah \& Luthfiyah, 2018). The researchers wanted to explain comprehensively about the participation of lecturers in implementing blended learning (Wayan Suwendra, 2018).

The research steps undertaken were setting goals to be investigated, formulating problems, determining the role of theory, and determining the mindset (Muri Yusuf, 2016). This research required in-depth notes from individuals or groups of individuals. For this reason, the instruments used for data collection, in addition to the researchers themselves, were supported by outside observers (Widi,
2018). Thus, the researchers, who were at the same time being data sources, explored information in various ways, including observations, interviews, and notes from individual experiences or behaviors.

\section{Results and Discussion}

Institut Agama Islam Negeri (IAIN) of Padangsidimpuan has four faculties, one of which is the Faculty of Tarbiyah and Teacher Training (FTIK) having courses in Islamic Religious Education, Mathematics Education, English Language Education, Madrasah Ibtidaiyah Teacher Education and Early Childhood Islamic Education (PIAUD). Each of these study programs aims to help students to become professional teachers. For this reason, the faculty provides courses related to education and teaching.

Each study program provides micro-teaching courses, except for the Early Childhood Islamic Education Study Program (PIAUD) which has just been offered, and none of the students has reached semester VI. Micro-teaching courses require digital-based learning tools in the form of micro spaces, projectors, CD players, DVDs, recorders, and voice control for prospective teachers. These tools should be present considering that the era of the industrial revolution 4.0 is that where all human work has turned to technology. "Preparation of innovative learning systems such as adjusting the learning curriculum and improving students' abilities in terms of Information Technology (IT), Operational Technology (OT), Internet of Things (IoT), and Big Data Analytics, as well as integrating physical, digital, and human objects, to produce competent and skilled college graduates" (Waluyo, 2014).

The digital aspect has become a technological basis in human life. The industrial revolution 4.0 provides new opportunities and challenges for everyone in the global competition. In the direction of an industrial revolution that is able to survive and keep up with the times, students should be equipped with 4C, namely critical thinking, creativity, communication, and collaboration (Rohida, 2018).

Students, in the era of the industrial revolution, must have critical thinking to produce creative ideas and innovations to be communicated to the public. Their creativity is very superior to the Industrial Revolution 4.0. In this term, lecturers play a significant role by conducting blended learning to build the process of interaction between lecturers, students, and learning resources (Ekawati, 2018).

Thus, the participation of lecturers is expected to guide, support and assist the students in the learning process. The face-to-face process remains the core of learning and is best combined with blended learning. Connecting the face-to-face learning system with online activities by implementing blended learning can result in successful 
learning and can organize it well. "Combination of face-to-face and online activities, blended learning thus holds great potential for organizing differentiated instruction in higher education" (Boelens, Voet \& De Wever, 2018).

As evidence of the importance of the combined face-to-face assisted by lecturers with e-learning, it was found that 24 lecturers were participating in applying the blended learning method. The lecturer participation was proven based on the lecturer work report. It was found that all lecturers in micro-teaching courses participated in applying the stati-rotation, lab-rotation, and individual rotation models. Six lecturers (25\%) worked in the English study program, six $(25 \%)$ in the Mathematics study program, six lecturers $(25 \%)$ in the Islamic Religious Education study program, and six others $(25 \%)$ in the PGMI study program. Furthermore, in term of the flipped classroom model, lecturers' work reports showed that lecturers give assignments to students, such as having them carry learning tools when they want to practice teaching, including education calendar, syllabus, Teaching Program Plan, and programs, both semester- and annual-based ones. Students fulfilled the tasks assigned by lecturers by doing it outside the face-to-face meetings. In this case, the participating lecturers implemented a flipped classroom, where learning time in class with homework was integrated and harmonized according to the micro-teaching curriculum. In fulfilling the assignments ordered by lecturers, the students did browsing and searching for the assignment materials through online coursework. That way, lecturers could use their teaching time by making assignments and learning projects. Lecturers and students combined the results of the face-to-face lecturers compiled from the project work with those the students browsed and written in the assignment sheets (Beaumont, 2018). It was found that twelve lecturers participated in implementing the blended learning model of the flipped classroom $(50 \%)$.

When distributing assignments in the context of teaching practice, the lecturers applied the flex blended learning model, a model that concerns to the students' abilities and talents. Students who mastered English were given the task to teach English based on their abilities, such as writing, reading, and conversation. Likewise, some prospective teachers of Islamic Education were able to deliver the materials of Jurisprudence, Al-Quran Hadith, Islamic Cultural History, or Akidah-Aklak. In this case, lecturers provided learning and teaching support based on flexibility according to the needs of these students without reducing and limiting the curriculum and content of the courses. This model is very supportive of the employment and meeting the needs of students (van Leeuwen, Bos, van Ravenswaaij, \& van Oostenrijk, 2018). The participating lecturers that applied the flex model and did supervision optimally were 24 lecturers $(100 \%)$.

Lecturer participation in the implementation of blended learning is also appearing in the A La Carte model. The students took online courses with previously recorded materials, in addition to learning materials got in the face-to-face class. However, the weakness of this model is that lecturers had no mastery to use learning applications optimally, so they need operators. Students also find it difficult to operate without lecturer socialization. Nevertheless, taking online courses and adapting them to materials recorded by students is very useful for repeating and deepening lecture materials, and strengthening student memory. This study found that there were only four lecturers (16\%) who applied the La Carte model. The campus, however, made this model an option in providing elective courses.

Another alternative in the blended learning method is the enriched virtual model, where students can complete all teaching materials online at home or elsewhere. As evidence of completing lectures online, students continued to attend face-to-face learning activities in class as needed. All micro-teaching lecturers, 24 people $(100 \%)$, applied this enriched virtual model.

Lecturer participation in implementing blended learning at the Faculty of Tarbiyah and Teacher Training (FTIK) of IAIN of Padangsidimpuan, based on the learning model, can be concluded from the following table:

Table 1. The Number of Lecturers implementing Blended Learning, based on Learning Model

\begin{tabular}{|c|c|c|c|c|c|c|c|c|c|}
\hline \multirow{2}{*}{ No } & \multicolumn{9}{|c|}{ Study Program Group } \\
\cline { 2 - 12 } & \multirow{2}{*}{ Blended Learning Model } & \multicolumn{2}{|c|}{ English } & \multicolumn{2}{|c|}{ Mathematic } & \multicolumn{3}{|c|}{ PAI } & \multicolumn{2}{c|}{ PGMI } \\
\cline { 2 - 12 } & Implementing Lecturer & Yes & No & Yes & No & Yes & No & Yes & No \\
\hline 1 & Stati-rotation & 6 & 0 & 6 & 0 & 6 & 0 & 6 & 0 \\
\hline 2 & Lab-rotation & 6 & 0 & 6 & 0 & 6 & 0 & 6 & 0 \\
\hline 3 & Individual rotation & 6 & 0 & 6 & 0 & 6 & 0 & 6 & 0 \\
\hline 4 & Flipped classroom & 4 & 2 & 3 & 3 & 3 & 3 & 2 & 2 \\
\hline 5 & Flex model & 6 & 0 & 6 & 0 & 6 & 0 & 6 & 0 \\
\hline 6 & A La Carte & 1 & 5 & 1 & 5 & 1 & 5 & 1 & 5 \\
\hline 7 & Enriched virtual & 6 & 0 & 6 & 0 & 6 & 0 & 6 & 0 \\
\hline
\end{tabular}

Source: Interview and Observation 
The variety of models applied by lecturers in implementing blended learning was due to various factors, one of which is the busyness of those with structural tasks, causing them to be unable to apply blended learning. Most lecturers, who did not have additional assignments, participated in implementing blended learning. They didn't have much time to develop learning through the internet. The next factor is the lack of understanding in operating the internet, both the hardware and the software which lecturers must understand because blended learning has learning applications which should always be updated. Moreover, the students' low economic level also made them less able to access internet devices, including networks and computerized systems.

Blended learning as digital-based online learning requires educational experts who can combine face-to-face with online learning methods, and must understand the conditions of the all-technological world of the industrial revolution. As explained by Thorne, blended learning is "a way to meet the challenges that adapt learning and development to individual needs by integrating the innovative and technological advancements offered by online learning with the interaction and participation offered in traditional learning" (Simarmata, 2017). Blended learning aims to facilitate learning by providing a variety of media that encourage students to make the best use of face-to-face contact in developing knowledge (Abdullah, 2018). Blended learning is an initial step to meet the demands of the industrial revolution 4.0 by giving birth to education 4.0 as well. Education 4.0 is a condition "in which educational phenomena can respond to the emergence of the need for revolution 4.0, where humans and machines are aligned to get solutions, solve problems, and of course also find the possibility of innovations" (Imaduddin, 2018).

The findings showed that blended learning is very effective and efficient to improve students' abilities. Thus, lecturers are expected to participate actively in the implementation. Matheos said, "It is clear that the implementation of blended learning is best practice for higher education and an enabler for HER. Blended learning has the potential to facilitate improved student engagement and performance, improved design, learning outcomes, and assessment, improved retention and reduced time to degree, adaptive and competency-based learning, new literacies and collaborations, skills for lifelong learning, optimization of resources/cost reduction" (Matheos \& Cleveland-Innes, 2018). The application of blended learning in universities facilitates increased student involvement and performance, improved design, learning outcomes, and assessment. Blended learning is a learning model that is adaptive and based on competence, literacy, and new collaboration that promise skills for lifelong learning and achievement of resource optimization.

\section{Conclusions}

Data on lecturer participation in implementing blended learning has been found, based on the models. Stati-rotation, lab-rotation, and individual rotation models were applied by all the lecturers, as many as 24 people $(100 \%)$, who supervised micro-teaching courses, in each study program. Twelve lecturers (50\%) applied the flipped classroom model. Twenty-four lectures (100\%) applied the flex one and conducted optimum supervision. Only four lecturers (16\%) applied A La Carte model. Meanwhile, the enriched virtual one was applied by 24 lecturers $(100 \%)$. Weaknesses in the implementation of blended learning were found when lecturers lacked understanding in internet operations and were not ready due to their busyness of doing other structural tasks. In the student side, their low economic level made them unable to access internet devices, including networks and computerized systems that always develop.

\section{Acknowledgements}

This study showed the hard work of all micro-teaching lecturers in the Faculty of Tarbiyah and Teacher Training (FTIK) of IAIN of Padangsidimpuan. We thank all the sixth-semester students who actively participate in the micro-teaching course.

\section{REFERENCES}

[1] Abdullah, W. (2018). Model Blended Learning dalam Meningkatkan Efektifitas Pembelajaran. FIKROTUNA, 7(1), 855-866. https://doi.org/10.32806/jf.v7i1.3169

[2] Beaumont, K. (2018). Google Classroom: An online learning environment to support blended learning. Compass: Journal of Learning and Teaching, 11(2). https://doi.org/10 $.21100 /$ compass.v11i2 2837

[3] Boelens, R., Voet, M., \& De Wever, B. (2018). The design of blended learning in response to student diversity in higher education: Instructors' views and use of differentiated instruction in blended learning. Computers \& Education, 120, 197-212.https://doi.org/10.1016/j.comped u.2018.02.009

[4] Christensen, C. M., Horn, M. B., \& Staker, H. (2013). Is K-12 Blended Learning Disruptive? Clayton Crestensen Institute, 48.

[5] Ekawati, N. E. (2018). Application of Blended Learning with Edmodo Application Based on PDEODE Learning Strategy to Increase Student Learning Achievement. Formatif: Jurnal Ilmiah Pendidikan MIPA, 8(1). https://doi. org/10.30998/formatif.v8i1.2303

[6] Graham, C. (2006). Blended learning systems: Definition, current trends, and future directions (pp. 3-21). 
[7] Imaduddin, M. (2018). Membuat Kelas Online Berbasis Android Dengan Google Classroom: Terobosan Pembelajaran Era Revolusi Industri 4.0. Yogyakarta: Penerbit Garudhawaca.

[8] Kurniasih, N., Sujito, Yulianti, Sudirman, A., Agustini Damayani, N., Paing, J., ... Jati Nugroho, F. (2019). The analysis on utilization of Unpad Library Management System by end-users using the Technology Acceptance Model. Journal of Physics: Conference Series, 1175(1). https://doi.org/10.1088/1742-6596/1175/1/012229

[9] Martikasari, K., \& Dharma, U. S. (2018). Kahoot: Media Pembelajaran Interaktif Dalam Era Revolusi IndustriI 4.0. Prosiding Seminar Nasional FKIP 2018. http://dx.doi.org/1 0.24071/snfkip.2018.19

[10] Matheos, K., \& Cleveland-Innes, M. (2018). Blended Learning: enabling Higher Education Reform. Revista Eletrônica de Educação, 12(1), 238-244. https://doi.org/10 $.14244 / 198271992524$

[11] Muh Fitrah \& Luthfiyah. (2018). Metodologi penelitian: penelitian kualitatif, tindakan kelas \& studi kasus. Sukabumi: CV Jejak (Jejak Publisher).

[12] Muri Yusuf. (2016). Metode Penelitian Kuantitatif, Kualitatif \& Penelitian Gabungan. Jakarta: Prenada Media.

[13] Nasir Zakaria, G. A., Nawi, A., \& Wekke, I. S. (2019). The effectiveness of implementing noble values through online problem-based learningamong students in higher learning institution. Journal of Advanced Research in Dynamical and Control Systems, 11(8 Special Issue), 540-556.

[14] Rohida, L. (2018). Pengaruh Era Revolusi Industri 4.0 terhadap Kompetensi Sumber Daya Manusia. Jurnal Manajemen Dan Bisnis Indonesia, 6(1), 114-136. http://dx .doi.org/10.31843/jmbi.v6i1.187

[15] Simarmata, J. (2017). Pembelajaran Campuran (Blended Learning). Universitas Negeri Medan. https://doi.org/10.31 227/osf.io/4v59a

[16] Susanto, Ratnawati, and Reza Rachmadtullah. 2019. "Model of Pedagogic Competence Development: Emotional Intelligence and Instructional Communication Patterns." http://www.ijstr.org/paper-references.php?ref=IJSTR-0819 -21204 (October 21, 2019).

[17] Susanto, R., Rozali, Y. A., \& Agustina, N. (2019). Development of pedagogical competency models for elementary school teachers: Pedagogical knowledge, reflective ability, emotional intelligence and instructional communication pattern. Universal Journal of Educational Research, 7(10), 2124-2132. https://doi.org/10.13189/ujer. 2019.071010

[18] Suprapto, A. (2019). Analisis dimensi kebutuhan pra implementasi e-learning untuk meningkatkan mutu layanan pendidikan kampus di era revolusi industri 4.0. ATTARBIYAH, 28(0), 81-97. https://doi.org/10.18326/tar biyah.v28i0.81-97

[19] UGM, F. F. (2019). Revolusi Industri 4.0. Sukabumi: CV Jejak (Jejak Publisher).van Leeuwen, A., Bos, N., van Ravenswaaij, H., \& van Oostenrijk, J. (2018). The role of temporal patterns in students' behavior for predicting course performance: A comparison of two blended learning courses. British Journal of Educational Technology, 0(0). https://doi.org/10.1111/bjet.12616

[20] Waluyo, M. E. (2014). Revolusi Gaya Belajar untuk Fungsi Otak. Nadwa, 8(2), 209-228. https://doi.org/10.21580/nw. 2014.8.2.577

[21] Wayan Suwendra, I. W. S. (2018). Metodologi Penelitian Kualitatif dalam Ilmu Sosial, Pendidikan, Kebudayaan dan Keagamaan. Bandung: Nilacakra.

[22] Widi, R. K. (2018). Menggelorakan Penelitian; Pengenalan dan Penuntun Pelaksanaan Penelitian. Jakarta: Deepublish.

[23] Yulianto, H. (2018). Peningkatan Partisipasi Riset Bagi Dosen. CARADDE: Jurnal Pengabdian Kepada Masyarakat, 1(1), 23-29. http://dx.doi.org/10.31960/caradde.v1i1.16 